\title{
Two Constitutional Cultures, Technological Enforcement and User Creativity: The Impending Collapse of the EU Copyright Regime?
}

\author{
Guido Westkamp
}

Accepted: 9 November 2021/Published online: 16 December 2021

(C) The Author(s) 2021

\begin{abstract}
In Pelham, the Court of Justice of the European Union and the German Federal Constitutional Court reached diametrically opposing conclusions on the relevance of freedom of art in copyright law. The different stances permit a speculative prediction - they can have immediate consequences for the predictable challenges against the new platform liability regime, and its associated dangers of widespread filtering and blocking. The article discusses the numerous constitutional implications, with specific attention given to the respective interests affected by the new regime (authors, exploiters, users, platforms) in light of the divergent approaches from the perspective of what appears to be two rather conflicting constitutional cultures: specific perceptions of fundamental rights and proportionality under German law versus an approach tending to emphasise market integration under the EU legal order. Recent assertions by the German Federal Constitutional Court redistributing the division of competences between national and EU law permit the prediction of a disturbing future collision course between the two systems, with potentially massive implications for EU copyright law by and large.
\end{abstract}

Keywords Copyright law · Platform liability · Freedom of art · Fundamental rights · German constitutional law $\cdot$ EU legal order

\footnotetext{
G. Westkamp $(\bowtie)$

Prof. Dr. jur, LL.M.; Chair in Intellectual Property and Comparative Law, Centre for Commercial Law Studies, Queen Mary University of London, London, UK e-mail: g.westkamp@qmul.ac.uk
} 


\section{Introduction}

The deadline for implementing the Directive on Copyright in the Digital Single Market (hereinafter "DSMD") ${ }^{1}$ has passed. Upload filters will become reality. The passionately debated Art. $17^{2}$ DSMD now imposes liability on certain platforms for acts of communication to the public committed by users, and liability can only be avoided by showing "best efforts" to make illegal content unavailable. The provision was premised on the previous jurisprudence by the Court of Justice, in which it was held that the right of communication to the public (Art. 3 InfoSoc Directive ${ }^{3}$ ) could extend to acts such as manufacturing and distributing devices permitting access to illegal content, and to operators of illegal file-sharing platforms. Consequently, the relevant safe harbour provision for host providers (Art. 14 E-Commerce Directive ${ }^{4}$ ) is repealed, and other elements applicable under (national) rules on secondary or (in Germany) disturbance liability (Störerhaftung) concepts ${ }^{5}$ - in particular, knowledge and control of content (an area largely unharmonised in the EU) - no longer apply for those platforms covered under Art. 17 DSMD. ${ }^{6}$ Instead, showing best efforts to remove illegal content is the only way to escape liability. The policy objective underscoring Art. 17 DSMD is disturbingly simplistic: copyright exploiters had identified a value gap, and platforms would, by and large, profit massively from unauthorised uses. Technological measures thus safeguard exploiters' existing distribution channels from disruptive competition.

This contribution addresses, centrally, the question of constitutionality of the new liability regime ${ }^{7}$ in light of the opposing decisions reached by the German Federal Constitutional Court and the Court of Justice of the European Union respectively in the Pelham (also known as the "Metal on Metal" 8 )

\footnotetext{
${ }^{1}$ Directive (EU) 2019/790 of the European Parliament and of the Council of 17 April 2019 on copyright and related rights in the Digital Single Market and amending Directives 96/9/EC and 2001/29/EC, OJ L 130, 17.5.2019, p. 92 (hereinafter "DSMD”).

2 Previously Art. 13 Proposal for a Directive of the European Parliament and of the Council on copyright in the Digital Single Market, COM/2016/0593 final - 2016/0280 (COD).

3 Directive 2001/29/EC of the European Parliament and of the Council of 22 May 2001on the harmonisation of certain aspects of copyright and related rights in the information society, OJ L 167, 22.6.2001, pp. 10-19 (hereinafter "InfoSoc Directive").

4 Directive 2000/31/EC of the European Parliament and of the Council of 8 June 2000 on certain legal aspects of information society services, in particular electronic commerce, in the Internal Market OJ L 178, 17.7.2000, pp. 1-16.

5 See Hoeren and Yankova (2012), p. 501.

6 Art. 17(6) and recital 66 DSMD. Article 17 DSMD, inter alia, does not apply to platforms with a turnover of less than EUR 10 million and where the average number of monthly unique visitors in the Union does not exceed 5 million.

7 See further - beyond copyright - van der Sloot (2015), p. 211.

8 The defendant had copied a sound snippet from the recording "Metall auf Metall" by German electronic music pioneers Kraftwerk, released on the album "Trans Europa Express" (first released in Germany 1977 - KlingKlang/EMI Electrola 1C 264-82306). They integrated that sound into a recording by German hip-hop artist Sabrina Setlur, released in 1999. The background to Kraftwerk's recording which is that of a moving train - is described in Flür (2017), p. 69 et seq.
} 
litigation ${ }^{9}$ a dispute entailing and raising countless problematic concerns between strong property protection and freedom of communication, and espousing entirely different perceptions on the status of fundamental rights under domestic German and EU secondary copyright law. In short, the Federal Constitutional Court asserted that, as a matter of freedom of art is guaranteed under Art. 5(3) of the German Basic Law, music sampling can be permissible notwithstanding any property right in sound recordings, and that courts needed to make a proportionate assessment via an analogous application of the free-use principle (Art. 24(1) of the German Authors' Rights Act, now repealed).

The Court of Justice held that the free-use clause was incompatible with the closed-list approach as regards limitations and exceptions under Art. 5 InfoSoc Directive. ${ }^{10}$ The free-use clause had consequently been repealed in Germany following the implementation of the DSMD. The position adopted by the Federal Constitutional Court, along with other recent decisions unrelated to copyright law, ultimately paves the way for this Court to secure competence for itself. The opposing decisions in Pelham, consequently, give reason to believe that the Federal Constitutional Court might discard Art. 17 DSMD as unconstitutional, alongside much wider assertions affecting the future relationship between German constitutionality perceptions and the EU legal order as a system much based on economic principles and market integration. The decisions therefore are highly relevant from a constitutional perspective. Both address the conflict between creativity and technological control, and between an open system of decision-making and the alleged "closed list" as regards exceptions under Art. 5 InfoSoc Directive.

\section{Article 17 DSMD: Liability, Enforcement and Creativity}

Article 17 DSMD will, undisputedly, incentivise platforms to adopt technological solutions so as to avoid liability, which will ultimately include upload filters and other forms of algorithmic monitoring of content. ${ }^{11}$ The most critical consequence of the new liability regime - the prospect of liability for potentially prohibitive damage payments ${ }^{12}$ - will ultimately incentivise platforms to strategically collude with exploiters so as to avoid that consequence. Article 17 DSMD therefore reduces access to works and, more importantly, creates an indubitable menace to creativity. Technological control, it is feared, will stifle and perhaps eliminate cultural participation and creativity at the expense of individual author and user

\footnotetext{
9 BVerfGE 142, 74; Case C-476/17 - Pelham GmbH and Others v. Ralf Hütter and Florian Schneider-Esleben, ECLI:EU:C:2019:624. There are, in total, 11 decisions in this litigation, which commenced in 1999. The preceding litigation will not be discussed here in detail.

${ }^{10}$ Recital 32 InfoSoc Directive ("This Directive provides for an exhaustive enumeration of exceptions and limitations to the reproduction right and the right of communication to the public").

11 See Frosio (2017), p. 199.

12 Husovec (2019a, b), pp. 92, 94 et seq.
} 
interests. ${ }^{13}$ Certainly, algorithmic enforcement cannot distinguish between permitted uses and evident infringement. ${ }^{14}$ The presence of protected subject matter, however small or commercially immaterial, will be sufficient to trigger automated blocking and removal. Even where users may be given the right to challenge technological eradication of uploaded content, for example, on the grounds of the right to engage in a transformative, referential or otherwise creative re-use of protected material, a chilling effect can still follow since any such complaints resolution mechanism - which may well result in liability for damages necessitates the disclosure of personal data. ${ }^{15}$ The continued applicability of relevant statutory exceptions such as for parody, pastiche, caricature and quotation under the InfoSoc Directive ${ }^{16}$ becomes relegated to symbolic law-making.

In the context of both existing and predictable constitutional challenges, ${ }^{17}$ therefore, the status apportioned to these exceptions, and the wider notion of freedom of art as a fundamental right underpinning access and participation in new communicative spheres, become pivotal. ${ }^{18}$ The central question is whether, from a constitutional perspective, the collateral damage that is done to creativity can be justified as a tolerable side effect in light of an overpowering need to legally safeguard and secure technological enforcement options. ${ }^{19}$

Obviously, resorting to an "unjust enrichment" topos hardly provides satisfactory justification. The implications of Art. 17 DSMD are not constrained to aspects of legitimacy of the more immediate interests of platform operators and commercial exploiters of copyright, but of course extend to those of authors and users. ${ }^{20}$ From a

\footnotetext{
13 See AG Saugmandsgaard Øe, 28.7.2020, Opinion in Joined Cases C-682/18 and C-683/18 Frank Peterson v. Google LLC and Others and Elsevier Inc. v. Cyando AG, ECLI:EU:C:2020:586. In its final judgment, the Court of Justice did not refer to fundamental rights, see Joined Cases C-682/18 and C-683/ 18 Frank Peterson v. Google LLC and Others and Elsevier Inc. v. Cyando AG, ECLI:EU:C:2021:503.

14 Burk (2019), p. 283.

15 See generally Yu (2015), pp. 455, 457.

16 Art. 17(7) DSMD, referring to the exceptions for quotations and parodies, pastiches and caricature under Arts. 5(3)(h) and 5(3)(k) InfoSoc Directive respectively. See further Quintais, Frosio, van Gompel, Hugenholtz, Husovec, Jütte and Senftleben (2019).

17 Republic of Poland v. European Parliament and Council of the European Union, action brought on 24 May 2019, <http://curia.europa.eu/juris/document/document.jsf?text=\&docid=216823\&pageIndex= $0 \&$ doclang $=E N \&$ mode $=1$ st $\&$ dir $=\&$ occ $=$ first $\&$ part $=1 \& \mathrm{cid}=8371710>$. The challenge seeks annulment of Arts. 17(4)(b) and 17(4)(c) DSMD.

18 See Wielsch (2008), p. 7 (noting also that, from a legislative perspective, user freedoms and property rights have equal status).

19 AG Saugmandsgaard Øe - whilst generally confirming the constitutionality of Art. 17 DSMD - also opined that the salient exceptions must remain available, and that preventive blocking affecting such legitimate uses would constitute a violation of fundamental rights; accordingly, the decision on the legitimacy of such uses can neither be made through subsequent redress mechanisms initiated by users, nor are platforms to adjudicate on permissibility through private dispute resolution mechanisms. See Case C-401/19, Poland v. Parliament and Council, ECLI:EU:C:2021:613 (Opinion). See further Geiger and Izyumenko (2019), pp. 138, 141.

${ }^{20}$ In Germany platform operators had previously always been successful in disputes with copyright holders since the requisite knowledge criterion had been found to be absent. The details of the mechanisms under German tort law concerning intermediary liability are outside the scope of this contribution. See Ohly (2014), p. 50.
} 
constitutional perspective, these intricate relationships require a legislative choice of whose interests will take precedence in light of the plethora of fundamental rights at stake. Here, two perspectives can be taken. First, an approach that emphasises, generally, the economic function of copyright under a "high level of protection" standard $^{21}$ and, second, an approach that highlights the function of copyright, in a more ideational sense, as an instrument to facilitate access and creativity. This is why the categorisation of creative re-uses in the context of user-generated content ${ }^{22}$ is so crucial $^{23}$ in the context of the new liability regime, in particular as regards the status and perception of user creativity beyond statutorily defined exceptions to copyright. The Federal Constitutional Court has shown that - as will be discussed ${ }^{24}-$ freedom of art depends on a holistic and open-ended balancing exercise, and this assertion in turn opens the perspective to a more general insight: that de minimis uses function as important preconditions for socially and culturally desirable participation. ${ }^{25}$

The divergent positions as regards the permissibility of music sampling and the relevance of freedom of art, as asserted by the German Federal Constitutional Court and the Court of Justice respectively, mark the last frontier in the constitutional test of interest balancing. Ultimately, as will be seen, the constitutionality of Article 17 DSMD under EU law may hinge on the central notion of the term "exception" under secondary law, as opposed to a much wider perception of freedom of communication as a fundamental right that underpins copyright law. In that latter sense, copyright is perceived not as a closed system regulating, on the basis of a normatively complete and consistent set of rules, a one-dimensional collision of interests between right holders and users, but as a regulatory framework premised predominantly on incentivising creativity, a principle that would immediately, and drastically, "correct" the exploiterbiased patterns of argument that underscore Art. 17 DSMD. The permissibility of de minimis uses, as highlighted in Pelham, thus has a constitutional dimension, and this is relevant for platform accessibility. The implications of the position adopted by the Federal Constitutional Court, and its robust insistence on the relevance of fundamental rights - above and beyond copyright law - exceed by far the old debate of whether fundamental rights may be used as an external defence to copyright infringement. The traditionally strained relationship between the two courts might escalate the debate to new pinnacles as both reflect entirely contradictory points of departure, instantaneously exposing rather differing perspectives as to what the central and most fundamental function of copyright should be, and whose interests - authors', users', exploiters', platforms' - should accordingly be considered as the central point of reference.

In the EU, the intersection between fundamental rights and copyright has, over time, become increasingly prominent. One reason was the coming into force of the EU Charter on Fundamental Rights following the Lisbon Treaty, ${ }^{26}$ but, even before

\footnotetext{
21 InfoSoc Directive, recital 9.

22 See generally Hoffmann and Klass (2017), p. 31.

23 Geiger, Frosio and Izyumenko (2019), p. 140 et seq.

24 See infra, 5.

25 See infra, 6.2.

26 The relevant jurisprudence started with Case C-275/06, Productores de Música de España (Promusicae) v. Telefónica de España SAU, ECLI:EU:C:2008:54.
} 
that, the Court of Justice had recognised proportionality as a central tenet of EU law in general. ${ }^{27}$ Its jurisprudence, in copyright law and beyond, clearly shows a departure from a rigid understanding solely oriented towards market integration aims,${ }^{28}$ including the protection afforded to platforms under the freedom to conduct a business $^{29}$ as well as in cases where copyright enforcement and privacy concerns collide. Similarly, the Court of Justice has taken a rights-based approach with regard to written exceptions and has elevated relevant exceptions to the status of (subjective) rights. ${ }^{30}$

However, and this became very clear following the Pelham decision by the Court of Justice, secondary law imposes limits on such judicial freedom, ${ }^{31}$ with an immediate effect on the conceptualisation of creativity and access to culture. Article 17 DSMD, overall, negates fundamental rights implications if monolithically premised on the protection of "right holders" (exploiters). The constitutional analysis would thus equate the principled protection of exploiter interests with a constitutionally opaque notion of a legislative obligation to protect commercial privileges under the IP clause in Art. 17(2) of the EU Charter, including the alleged rights of exploiters as both owners of (proprietary) producer rights and as licensees of authors' rights. There is a dense and convenient pattern of argument for stronger and monopolistic protection of commercial interests that is deeply ingrained in the overall normative hierarchy and the underlying policy objectives as (implicitly) formulated during the gestation of the InfoSoc Directive. The InfoSoc Directive is predominantly premised on speculation ${ }^{32}$ that a "high level" of protection should be assured $^{33}$ so as to incentivise the copyright industries to adopt (then) new online business models. Predominantly, this private ordering concept ${ }^{34}$ was to be achieved through legally protecting technological protection measures. ${ }^{35}$ Obviously, these privileges are perpetuated under Art. 17 DSMD. The InfoSoc Directive and the DSMD exceptions and limitations have therefore been marginalised. ${ }^{36}$

\footnotetext{
27 Christoffersen (2017), p. 19 et seq.

28 Sganga (2019), p. 56.

29 Case C-70/10, Scarlet Extended NV v. Belgische Verenigung van Auteurs, Componisten en Uitgevers CVBA (SABAM), para. 43, ECLI:EU:C:2011:771; Case C-314/12, UPC Telekabel Wien GmbH v. Constantin Film Verleih GmbH and Wega Filmproduktionsgesellschaft mbH, ECLI:EU:C:2014:192, para. 61.

${ }^{30}$ Case 469/17, Funke Medien NRW GmbH v. Bundesrepublik Deutschland, ECLI:EU:C:2019:623; Case 516/17, Spiegel Online GmbH v. Volker Beck, ECLI:EU:C:2019:625.

31 See infra, 4.2.4.

32 Westkamp (2011a, b), p. 601.

33 InfoSoc Directive, recital 9.

34 Cahir (2007), p. 73.

35 Art. 6(1) InfoSoc Directive. See Dusollier (1999), p. 285; Westkamp (2009), p. 104; Westkamp (2011a, b), pp. 601, 631 et seq.

${ }^{36}$ Cf. Art. 6(4) InfoSoc Directive (only some limitations and exceptions can be rendered enforceable where TPMs are applied).
} 


\section{Proportionality and the Medium of Money: Paying Authors Under the First German Draft}

In Germany, Art. 17 DSMD has finally been implemented ${ }^{37}$ in a manner closely mirroring its wording. The final text is a result of a radical political turnaround that ultimately eradicated the initial licensing solution. The German government was well aware of the problematic implications of Art. 17 DSMD, and declared that filtering and blocking solutions should be avoided. ${ }^{38}$ Proportionality, of course, is a central principle of German constitutional law, and freedom of communication occupies a particularly elevated position in the constitution's objective order of values. ${ }^{39}$ Consequently, the draft proposal on implementing Art. 17 DSMD $^{40}$ attempted to relativise the strong reliance on commercial privileges. The suggested solution relied principally on the "medium of money": a general yet rather speculative promise of collective and statutory licensing solutions. Platforms would have escaped liability where they could demonstrate "best efforts" to seek and agree licences with right holders, a solution flanked by the introduction of a new extended collective licensing scheme ${ }^{41}$ covering platform uses (which was kept) so as to ease the availability of permissions and enhance compensated uses in general. Authors, not other right holders, would be compensated by platform operators (via collecting societies) for licences agreed with platforms, as well as for certain defined de minimis ("technically verifiable") uses and for uses falling within the remit of the pastiche exception ("technically non-verifiable uses").

In the ensuing debate, right holders took offence, especially aiming at the new de minimis "exception". It was argued that even the smallest snippets might have commercial value, and that in any case the de minimis clause violated EU law following the closed-list principle under Art. 5 InfoSoc Directive, ${ }^{42}$ and that a "sui generis" approach would not rescue the new clause, given that Art. 17 the DSMD (arguably) did not provide a legislative basis for proportionality deliberations outside of the salient exceptions, ${ }^{43}$ and that the InfoSoc Directive would not allow "new" exceptions. ${ }^{44}$ Subsequently, the final text as adopted transformed the best

\footnotetext{
37 Urheberrechts-Diensteanbietergesetz [UrhR-DaG](German Copyright Service Providers Act 2021), in force from 1.8.2021.

38 Erklärung der Bundesrepublik Deutschland zur Richtlinie über das Urheberrecht und verwandten Schutzrechte im Digitalen Binnenmarkt, insbesondere zu Artikel 17 der Richtlinie, https://www.bmjv.de/ SharedDocs/Downloads/DE/News/PM/041519_Protokollerklaerung_Richtlinie_Urheberrecht.pdf?_ blob=publicationFile \&v=1.

39 Ever since BVerfGE 7, 198 - Lüth. Translation is available from https://germanlawarchive.iuscomp. org/?p=51.

${ }^{40}$ Referentenentwurf des Bundesministeriums der Justiz und für Verbraucherschutz, Entwurf eines Gesetzes zur Anpassung des Urheberrechts an die Erfordernisse des digitalen Binnenmarktes [2.9.2020], https://www.bmjv.de/SharedDocs/Gesetzgebungsverfahren/Dokumente/RefE_Urheberrecht.pdf?_blob= publicationFile \&v=7.

41 (New) Art. 51 of the German Collecting Societies Act, which has been kept.

42 Rosati (2020).

43 Art. 17(7) DSMD, which relates only to parodies, pastiches, caricatures, and quotations.

44 Art. 17(7) DSMD. See further Hofmann (2020), pp. 665, 666; Stieper (2020), p. 1.
} 
effort principle back so as to comply with the text of Art. 17 DSMD; ${ }^{45}$ consequently, platforms now avoid liability predominantly where technological control mechanisms have been applied. ${ }^{46}$ Ultimately, users may still rely on the parody, pastiche and caricature exception, and authors will still have a direct claim against platforms for such uses; however, it is very arguable that a chilling effect will follow and that the central provisions for transformative or referential uses will become symbolic at best, since right holders may challenge any use flagged as permissible via the complaints procedures that platforms will institute. ${ }^{47}$ Users therefore not only face disclosure of their personal data but, more worryingly, claims to damage payments. In essence, the final text thus disregards the pertinent intersection between de minimis uses and freedom of art in the context of user creativity, ${ }^{48}$ which leads directly to the intricacies as stressed that may be extrapolated from the approach taken by the Federal Constitutional Court in Pelham.

The changes between the first draft and the final text may seem technical and minor at first glance, but overall this is not true. The final version of the new law reinstates technological enforcement opportunities as its central tenet, and materially reduces any incentive for right holders to grant licences. The potential income for authors for permitted uses is drastically reduced, and instead platforms and users face exposure to claims for damages. ${ }^{49}$

It is still worthwhile to briefly analyse the first draft proposal in the context of legislative choice. The first draft was almost revolutionary. It departed from a solution concentrating on the collision of interests between right holders and platforms. It contained a number of features that would shift the focus centrally towards the respective positions of authors and users. In particular, it avoided, at least speculatively, any technological enforcement by transforming the best effort criterion under Art. 17 DSMD from a norm carrying an obligation to filter towards an obligation on platforms to negotiate licences. It thereby also emphasised the fundamental insight that both interests (authors' and users') are complementary rather than antagonistic, in keeping with the basic function of copyright law as a precondition for creativity and free communication. ${ }^{50}$ Any residual claim based on a loss of potential income in the context of the constitutional right to property had

\footnotetext{
45 See also European Commission (2020) Targeted Consultation Addressed to Participants in the Stakeholder Dialogue on Art. 17 of the Directive on Copyright in the Digital Single Market (27.7.2020), https://ec.europa.eu/digital-single-market/en/stakeholder-dialogue-application-article-17-directivecopyright-digital-single-market. See further Leistner and Metzger (2017), p. 381.

46 The de minimis rule has partially survived in the final text, but now the provision (Art. 10 of the German Copyright Service Providers Act) no longer constitutes an exemption but a rebuttable presumption of legitimacy. Right holders may therefore challenge the permission to use small parts. In addition, the new provision excludes any use of commercially valuable portions of works and subject matter and, importantly, does not apply to commercial users.

47 The final text provides for both internal complaints procedure mechanisms and the establishment of external bodies. Access to courts is guaranteed (Arts. 13-15 of the German Copyright Service Providers Act).

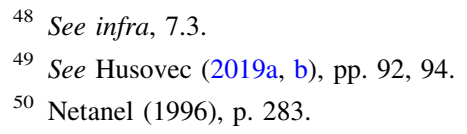


been resolved through the introduction of statutory licences for the benefit of authors. The addition of (collective) statutory licences, including both de minimis uses and parodies, etc. ${ }^{51}$ injects a logical and most central element into that system of proportionality: first, the prospect of new sources of income eradicates reliance on the constitutional right to property from the perspective of authors, and, similarly, also excludes arguments based on market conflicts. Second, the availability of income to authors would (in the absence of a compulsory-licences solution) have motivated authors' associations to exert pressure on exploiters to concurrently engage in licensing negotiations with platforms. Under these conditions, ruling out technological enforcement, the copyright industry would fare better accepting licensing solutions. From a more theoretical angle, the concept was fundamentally premised on reducing the complexity in assigning an equal weight to the various interests (while ensuring a constitutionally sound choice); the proposal clearly exposed that, for instance, the freedom to conduct a business ${ }^{52}$ was a fundamental right upon which platforms relied successfully in the past. That fundamental right can thus be reconstructed as a right subservient to user interests, and thereby as serving communicative freedom and creativity to the highest degree possible under the strictures of the DSMD. The draft further reflected that exploiter interests are subservient to those of authors as regards the distribution of income. ${ }^{53}$

Article 17 DSMD, in contrast, establishes a normative preference for code-based solutions, safeguarded, it may be argued, by Art. 17(2) of the EU Charter. The provision thereby creates a normative hierarchy that permits the conclusion of legislatively tolerable "collateral damage" for creativity, especially as regards the common reliance on property rights of producers. ${ }^{54}$ However, solutions that ignore less intrusive mechanisms (such as remunerating authors ${ }^{55}$ ) arguably violate fundamental rights for being disproportionate, and would obviously cast much doubt on whether Art. 17 DSMD could pass constitutional scrutiny. Both strands of reasoning are reflected in the respective decisions in Pelham - and much depends here on whether a commercial or a constitutional, a domestic or an EU perspective, is adopted.

\section{Pelham, Property and Freedom of Art}

The decisions in Pelham can be contrasted on many levels. In short, the Federal Constitutional Court was concerned with domestic perceptions of freedom of art,

\footnotetext{
51 The final text maintained that authors would receive payment for parody, pastiche and caricature, which represents a slight extension of the initial draft.

52 Art. 16 of the EU Charter and Art. 12 of the German Basic Law.

53 See infra, 5. For a discussion on author/exploiter conflicts see Westkamp (2008), p. 55 et seq.; Case C-572/13, Hewlett-Packard Belgium SPRL v. Reprobel SCRL, ECLI:EU:C:2015:750, paras. 36 et seq.; Case C-277/10, Martin Luksan v. Petrus van der Let, ECLI:EU:C:2012:65; German Federal Constitutional Court (2010) GRUR 999, 1002 - "Printers and Plotters"; German Federal Constitutional Court (2006) Neue Juristische Wochenschrift (NJW) 596, 598 - Xavier Naidoo.

54 Ladeur (2016), p. 447.

55 Senftleben (2019), p. 1.
} 
whilst the Court of Justice sought to maintain the consistency of the EU legal order. The fundamental conflict thus is between an open system of assessment and market integration concerns. ${ }^{56}$ For the Court of Justice, the recognition of fundamental rights still depends on what secondary law permits, and it only permits certain proscribed uses for particular purposes - there is no solution as regards a more comprehensive understanding of the general status of freedom of art in the EU legal order, i.e. beyond individual disputes. Therefore, the opposing decisions raise numerous questions as regards the relationship between national and EU law, and more specifically as regards the status of exploiter rights and the treatment of referential and transformative uses under rather different conditions: an open, constitutionally informed assessment versus a system that insists on supremacy and market integration.

\subsection{Freedom of Art as an Open Clause: A View from German Constitutional Law}

In Pelham the Federal Constitutional Court conducted a classic fundamental rights analysis under national constitutional $\operatorname{law}^{57}$ and concluded that courts must, when assessing the conflict between the property right in sound recordings and freedom of art, demonstrate recognition of the specific status of freedom of art as a fundamental right in the context of a proportionality assessment, having specific regard to the use of works in a specific genre (such as hip-hop). The decision therefore reiterates once more that constitutional law requires copyright norms to be assessed adaptively. ${ }^{58}$

Notably, the Federal Constitutional Court neither asserted that freedom of art takes precedence in all cases concerning the use of snippets for the purpose of music sampling nor established a new exception to copyright. However, the Court stressed the importance of the right to freedom of art as a mechanism to potentially correct the effects of over-emphasising the status of producer rights under the constitutional right to property, a contention that immediately raises uncomfortable questions as regards the function of neighbouring producer rights in general and the rationale of these rights as a foundation for rebutting freedom of speech concerns in the context of uses on platforms. The basic contention of the Federal Constitutional Court thus can be described as demanding nothing more than the recognition of the relevance of freedom of art in a cultural sub-genre, and so the Court emphasised the need for a proportionality assessment applicable, in theory, to any dispute where freedom of speech is implicated. For that reason, it was irrelevant whether the dogmatics of copyright law permitted such balancing; the Court left it to the judiciary to apply, if necessary, the free-use principle under (then) Art. 24(1) of the German Authors' Rights Act by way of analogy. 59

\footnotetext{
56 See Hugenholtz (2013), pp. 57, 63 et seq.

57 Mimler (2017), p. 119.

58 German Federal Constitutional Court (2010) GRUR 999, 1002 - "Printers and Plotters".

59 On the misguided application of the free-use clause to investment rights in Pelham, see Wielsch (2016).
} 
Thus, freedom of art, as a (subjective) right, qualifies the right to property, and would arguably always trump that right where the commercial impact upon the right holder's market is minor, that is, where the use in question does not substitute for the original in economic terms. A further important point is that the Federal Constitutional Court did not, in compelling courts to balance the interests through a proportionality assessment, pre-establish any specific criteria. This means that both the commercial and non-commercial interests of authors do of course remain relevant. In short, the decision provides a framework that is highly relevant in the context of platform liability. Particularly as far as the debate over transformative or referential uses is concerned, it shifts the focus predominantly to the legitimate expectations of both authors and users and, most importantly, relegates commercial interests to one aspect of the assessment rather than perpetuating a monolithic understanding of copyright as property. The final conclusion is that in terms of constitutional law there is no qualitative difference between the work and the alleged copy: creative re-uses are afforded the same degree of protection as any other form of creativity resulting in what copyright doctrine coins as a work. Constitutional law thereby disables doctrinal strictures in EU copyright law: the inherent automatism under copyright law - the formalistic reasoning in terms of a work/infringement dichotomy and a resultant "rule and exception" relationship - is insignificant from the perspective of constitutional values. Freedom of art is given the status of an equal right in the framework of an objective order of values. ${ }^{60}$ The Pelham decision, consequently, eradicates the causal relationship and inherent differentiation between a work (original) and a copy in the sense of an axiomatic dominance of protected subject matter over limited and purpose-bound uses, and consequently eliminates the conventional normative hierarchy in copyright. The point of departure in the assessment is set as a uniform and holistic notion of creativity as the central function of copyright law. However, the Court of Justice would not endorse that approach.

\subsection{Property, Producer Rights and the Court of Justice}

The response by the Court of Justice was to set clear limits on any notion of an extended freedom of art approach that goes beyond the closed-list principle in Art. 5 InfoSoc Directive. In doing so it implicitly rejected any notion of subjective user rights. Under a more generalised reading, the Court thereby accentuated the basic assertions leading to the principle of a high level of protection. The decision, as regards Art. 13 of the EU Charter of Fundamental Rights, shows a rather constrictive and overall flawed conceptual approach. Some proportionality deliberations have been made, though, which resulted in an awkward new principle of

\footnotetext{
${ }^{60}$ BVerfGE 7, 198 - Lüth. See also BVerfGE, 120, 274, 303 et seq. - Online Searches (asserting that the dangers of technological development and its potential for surveillance must be sufficiently recognised and balanced by the legislator, and that constitutional law must fill in any gaps in protection); BVerfGE 65, 1, 43 - Population Census (highlighting the dangers of surveillance as creating a psychological barrier to the free development of one's personality, which famously resulted in the formulation of a new fundamental right to informational self-determination under Art. 2 of the German Basic Law).
} 
perceptibility as the guiding distinction between permitted and prohibited music sampling.

\subsubsection{The Perceptibility Solution and the Status of Producer Rights}

The Court of Justice, of course, is bound to safeguard uniformity and market integration objectives. ${ }^{61}$ Unsurprisingly, it rejected freedom of art as a fundamental point of departure. Instead, the Court reinstated secondary copyright law as the guiding principle - since the InfoSoc Directive contained a closed list of exceptions, the free-use provision that the Federal Constitutional Court had wanted to employ as a vehicle for a proportionality assessment was declared as incompatible with EU law. Creative uses not covered by one of the salient exceptions are, the Court of Justice concluded, impermissible because such approach would defy a uniform understanding of the reproduction right, as applied to producers of sound recordings. Instead, the Court found a different solution in that the rights in sound recordings are subject to perceptibility, this solution being much in the sense of a compromise not just between the interests of the parties, but probably more so to leave some degree of protection to freedom of art. The perceptibility standard raises more questions than it answers and, more critically, appears to introduce an alien criterion that - as regards producer rights - seems devoid of meaning and persuasiveness, especially so because the "perceptibility" solution was obviously chosen as an escape route from an assessment that would have raised questions as to the function of the IP clause under Art. 17(2) of the EU Charter ${ }^{62}$ with respect to, specifically, the rationale for protecting producer rights vis-à-vis competing claims to freedom of art.

The flaw in the perceptibility criterion is not only that it largely leaves open who the addressee of such test is supposed to be, and that therefore the conclusions that may be drawn can hinge on rather arbitrary considerations, but also that the Court's "escapism"63 produces even more problems because it does not fit with rights that are granted solely to protect investments. Certainly, there is a discernible desire to create some balance and to avoid a generally absolute standard of protection, and between the lines - there are some proportionality considerations so as to avoid a notion of absolute producer rights. One may assume that the Court did not just refer to the simple audibility of a sound in another work, but that it, to some extent, permitted de minimis uses unless there was a certain danger of confusion. However, such danger cannot relate to an investment, only to the author's personality embodied in the original work. The Court, presumingly, established a somewhat curious notion that music sampling can detrimentally impact certain non-economic

\footnotetext{
61 Art. 19(1) TEU.

62 See further Husovec, (2019a, b), p. 840.

63 A different escape route had previously been formulated by the German Supreme Court, asserting that the defendant could escape liability by technically recreating the sampled sound. See BGH (2013) GRUR 614 - "Metall auf Metall II". The last decision by the Supreme Court in this matter referred the perceptibility issue back to the Higher Regional Court on matters of fact. BGH, I ZR 115/16, 30.4.2020 Metall auf Metall IV, https://openjur.de/u/2230139.html.
} 
concerns of authors rather than producers. ${ }^{64}$ But obviously it is an ill-suited concept when applied to commercial interests in investments in sound recordings. In Germany, that probable intention of the Court of Justice to design some space for creativity, within the boundaries of the closed list, had the opposite effect in the context of platform liability, where that fundamental concept protecting insubstantial parts ultimately led to the abolition of the de minimis exception under the first draft.

\subsection{2 "Perceptibility" and the Licensing Prerogative}

More precarious, then, is a different contention that may be developed in favour of producer interests: that perceptibility is to be understood as meaning that producers may object on the basis of a danger of confusing the listener as to the existence of a permission or licence (i.e. a claim, based on unfair competition, to "false endorsement"), which indeed would result in cementing the bias towards exploiter rights by introducing an all-embracing prerogative - of course, licensing markets for music samples do exist, and accordingly such type of confusion may be caused. If the mere opportunity to license is sufficient for establishing a right to property in constitutional terms, the result is a complete and wholesale derogation of user rights. Admittedly, and especially in UK jurisprudence, ${ }^{65}$ the notion of factual licensability in practice often provides a convenient pattern of argument in favour of exploitation rights based on property, ${ }^{66}$ and the same contention had been made in Germany, which produced the most convenient argument in the Pelham litigation saga - that the investment rationale underpinning rights in sound recordings would automatically and absolutely extend to any snippet of recorded sound. ${ }^{67}$ Obviously, that line of reasoning eradicates any reliance on conflicting rights, and further eliminates any obligation to even consider mitigating concerns under a proportionality assessment, as is otherwise often required as a central tenet of EU law. ${ }^{68}$ It would be at this juncture that the divergences between the Court of Justice and the German Federal Constitutional Court as regards the constitutionality of Art. 17 DSMD become most observable. A clear exposition of the function of producer rights under the constitutional property clause within the equilibrium of interests remains absent.

\subsection{3 "Licensability" as Property}

A more profound investigation into the societal function of producer rights would probably have yielded uncomfortable conclusions, because the mere licensability of

\footnotetext{
${ }^{64}$ Which seems to rely upon similar restrictions on the right to parody in some Member States, for example in the judicature on the parody exception under Art. L. 122-5-4 of the French Code de la propriété intellectual (CPI). See Lucas-Schloetter (2019), pp. 99, 101.

65 See Griffiths (2017), p. 64 (discussing the implications of previous UK jurisprudence on the new parody exception (Sec. 30A(1) CDPA 1988)).

66 Westkamp (2019), pp. 41, 52 et seq.

67 As criticised by Hoeren (2000), pp. 113, 128 et seq. (arguing that the scope of rights in sound recordings should not exceed the scope afforded to music authorship).

68 See Christoffersen (2017), p. 19.
} 
"snippets" hardly says anything about the function of producer rights from a constitutional point of view. ${ }^{69}$ Licensability is a result of a property right but not the precondition for its existence. The near circular argument that orbits around the property notion in this regard can easily be confuted: the function of neighbouring rights was, historically, only to prevent, speculatively, the economically undesirable consequences of mass "piracy" and to prevent straight copies from entering the market - not because producers had fundamental rights that would oblige the legislator to introduce specific neighbouring rights, but because permitting trade in infringing copies would reduce and potentially eradicate the motivation to invest in the first place, a contention that shows that producer rights were contingent on the protection of authors, since, of course, authors' income depended on marketability. There is broad consensus that digitisation has changed that perception, given the proliferation of highly diverse interests. ${ }^{70}$ It may suffice here to reiterate that strong producer rights and ideational interests of authors can conflict, and that widespread filtering is a solution that benefits commercial interests without incorporating authors' interests in participation in culture. Thus, the general obligation of the legislator to provide for property rights protection ${ }^{71}$ as regards the investments made by certain exploiters is limited at least where these rights are not exercised in line with authors' interests. ${ }^{72}$ Where, for example, conflicts arise as to the allocation of payments, the interests of authors commonly take precedence, ${ }^{73}$ a proposition that corresponds to a more exact understanding of the normative hierarchy that exists between authors' and exploiters' interests. ${ }^{74}$ Ultimately, investment protection in the context of neighbouring rights requires justification, in that the alleged copy economically serves as a substitute.

\subsubsection{Closed List and Technological Control: The Status of Exploiter Rights}

In sum, the approach taken by the Court of Justice in Pelham sets in motion a debatable pattern of argument that is based on the adage that "what is worth copying is worth protecting" but which now includes the possibility to rely on codebased enforcement as a right in itself. The DSMD perpetuates the basic idea that the high level of protection to be afforded to "right holders" includes control over access and use where technological measures have been applied (Art. 6(1) InfoSoc Directive), and the rationale for technological protection is identical under both Art. 6 InfoSoc Directive and Art. 17 DSMD, that is, to safeguard online business models through facilitating direct contracts with consumers ${ }^{75}$ and, later, through

\footnotetext{
${ }^{69}$ Hugenholtz (2019), p. 1006; Hoeren (2000), pp. 113, 128 et seq.

70 See Elkin-Koren (2017), p. 132.

71 See Hufen (2019), § 38 para. 15, p. 690 et seq.

72 German Federal Constitutional Court (2006) Neue Juristische Wochenschrift (NJW) 596, 598 - Xavier Naidoo.

73 Case C-572/13, Hewlett-Packard Belgium SPRL v. Reprobel SCRL, ECLI:EU:C:2015:750, paras. 36 et seq.

74 See Case C-277/10, Martin Luksan v. Petrus van der Let, ECLI:EU:C:2012:65. See also German Federal Constitutional Court (2006) Neue Juristische Wochenschrift (NJW) 596, 598 - Xavier Naidoo.

75 Westkamp (2011a, b), pp. 601, 623 et seq.
} 
safeguarding these business models from disruptive competition instigated by platforms. Both provisions thereby fashion an implicit normative hierarchy secondary law imputes, and reinforces, an understanding of absolute control, which can then be effortlessly integrated into the constitutional protection of property, a position that may additionally cement the bias towards commercial interests in that conflict with normal exploitation (Art. 5(5) InfoSoc Directive) is alleged. Thus, producer rights sit atop of that hierarchy, and it can easily follow from such perception that both Art. 6 InfoSoc Directive and Art. 17 DSMD are based upon the identical principle of proprietary protection that engulfs any "subject matter", however insubstantial or economically irrelevant. The next step in that line of argument is similarly effortless: claims to other interests can be maintained so as to achieve some fair balance on paper - Art. 6(4) InfoSoc Directive contains some exceptions and limitations that can be enforced where technological protection measures (TPMs) have been applied. In practice, this hardly happens, ${ }^{76}$ but - more importantly - under Art. 6(4) InfoSoc Directive, TPM protection excludes reliance on any exception that permits culturally significant uses, thus disregarding, for example, the right to quote and the right to parody. In any case, no limitation or exception under Art. 5 InfoSoc Directive can be enforced vis-à-vis services. ${ }^{77}$ Article 17 DSMD follows, in this regard, the same principle - that potentially conflicting interests of users and authors can be dispensed with without creating intrasystemic inconsistencies, as regards both the consistency of secondary law as such and, more importantly, the overall consistency of the EU legal order.

Today, there are very dissimilar views on the function of producer rights, whether derived from statutory ancillary rights or resulting from licensed author rights. Producer rights are correctly understood as being devoid of any particular societal function ${ }^{78}$ that could reasonably underpin arguments based upon constitutional protection. ${ }^{79}$ It is here that the Pelham decision leaves a large gap in the future assessment of how the divergent interests relate to each other, since necessarily the eschewal of the Court of Justice to engage with the fundamental rights dimension of the dispute provides one of the central arguments that can be raised in favour of widespread technological control. The tenacity of the licensability argument has, as mentioned, led to the abolishment of the de minimis rule previously foreseen in the first German proposal (because "snippets can be commercially valuable"). Yet again, the apodictic exclusion of any claim to fairness outside of the salient exceptions reinforces notions of property rights as constitutional guarantees ${ }^{80}$ afforded to exploiters irrespective of whether authors might fare better under a less intrusive solution such as widespread licensing.

Producer rights are, following the Pelham decision, misunderstood in their function. On closer inspection, a function-oriented analysis will immediately disqualify any of the attitudes that are conventionally voiced to support "strong"

\footnotetext{
76 Akester (2009).

77 Art. 6(4)(4) InfoSoc Directive.

78 Hugenholtz (2019), p. 1006.

79 Luhmann (2015) [originally published 1970], p. 360; Luhmann (1981).

${ }^{80}$ See also de Beer (2005), p. 89.
} 
producer prerogatives. Again, the perhaps most imperative consequence of the German licensing model in terms of a constitutional assessment would have been to highlight such function of the (subjective) right as being subservient to authors' interests. In essence, the rejection of freedom of art, and any other mechanisms that may be employed under national law to concretise that fundamental guarantee by the Court of Justice, is quite simply a consequence of strictures imposed by the InfoSoc Directive itself. The autonomous concept underlying the notion of reproduction, and the constricted status of exceptions as pertaining to a set of predefined purposes, are direct results not of interpreting secondary copyright law but of establishing metarules so as to demarcate areas of competence.

The exclusion of the fundamental rights dimension then causes further inconsistencies. Certainly, to recap, the Federal Constitutional Court considered any creative re-use as a priori permissible, subject to an incremental development of parameters and criteria to be adopted by way of proportionality and value judgements. Structurally, no right automatically takes precedence. The criteria will of course depend on the relative strength of the interests. In Pelham, the claim to property solely reflected the commercial interest. However, what the claimants were pursuing was, at least speculatively, rather different, motivated by a claim to artistic integrity. In that context, the conceptual approach taken by the Federal Constitutional Court, insisting on proportionality, permits further observations. It illustrates four important aspects: first, that the interests at stake in Pelham are, in reality, not of a commercial but of an ideational nature; second, that copyright disputes must, as a matter of constitutional law, include proportionality deliberations; third, that based on these assertions - proportionality requirements cannot, very arguably, be subject to market integration aims, thus potentially reversing the normative hierarchy between EU and national law; and fourth, the approach by the German Federal Constitutional Court also demonstrates that the rejection of freedom of art by the Court of Justice is inconsistent with its own jurisprudence where commercial interests are taken out of the equation.

\section{Artistic Integrity and Open Assessments: Transformative Use, Freedom of Art and the Evolution of Value Judgements}

\subsection{Openness and Ideational Interests: From Deckmyn to Pelham}

Intriguingly, both the Deckmyn decision ${ }^{81}$ and the decision by the Federal Constitutional Court in Pelham display a structurally identical pattern of decision making. In Deckmyn, the Court of Justice recognised a wide-ranging space for parody, subject only to discrimination. Both decisions therefore allow a broad choice of criteria, which may be based on considerations as to the respective quality of speech, rather than following from a predetermined property/exception architecture. There is a profound advantage: an incremental development of rules and

\footnotetext{
${ }^{81}$ Case C-201/13, Johan Deckmyn und Vrijheidsfonds VZW v. Helena Vandersteen, ECLI:EU:C:2014:2132.
} 
principles can much more easily respond to social and technological change. Indeed, in Deckmyn, the Court of Justice arguably proposed nothing other than a classical and open-ended constitutional proportionality test: that the right to parody is limited only by conflicting rights emanating from personal dignity, and that commercial prerogatives are irrelevant. If so, an awkward question as regards the closed-list principle arises: if such open-ended structure is applicable to the salient exceptions under Art. 5(3)(k) InfoSoc Directive, then the Court admits that the central feature that describes parody (humour or mockery), pastiche (tribute) and caricature (distortion) - reference through transformation - is an immediate reflection of freedom of art, directly applicable to any copyright dispute but subject predominantly to proportionality requirements - and, of course, reference requires the identifiability of the work, or style, to which such reference is made. It is then a different question whether each of these elements can meaningfully be construed individually and in isolation, as the Court of Justice seems to purport. But aimlessly following the dictionary meaning appears imprudent. "Parody" or "pastiche" may have specific connotations in literary or cultural studies, but these have little to say about the criteria that should apply in a balancing exercise, and their respective weight in light of constitutional value judgements. Much, therefore, speaks for a holistic understanding, proximate to the transformative use element as employed in the United States fair-use test, ${ }^{82}$ an approach certainly commensurate with the obligations to recognise freedom of art under Art. 13 of the EU Charter. Freedom of art already has its place in the closed list, and it is immaterial whether such conclusion is reached via a direct application of Art. 13 of the EU Charter or an extensive reading of "pastiche" ${ }^{83}$ If so, Art. 5(3)(k) InfoSoc Directive is to be understood as a broad general clause, an immediate reflection of Art. 13 of the EU Charter, and could easily have been applied by way of analogy to music sampling.

\subsection{Integrity and Personality Rights: Fairness Criteria Outside the Property Topos}

This advance towards such amplified constitutional sensitivity mirrors the structure of decision making typically adopted in cases where personality or privacy interests conflict with other fundamental rights such as media and information freedom. Here, a multiplicity of parameters and criteria, on both sides of the dispute, can be developed. As regards the law on general personality rights, such as the right to one's own image, ${ }^{84}$ a distinction is usually made between the commercial appropriation of personality aspects and cases that affect (only) ideational interests. In cases of commercial appropriation, the defendant cannot, as a rule, rely on freedom of communication. But even where an image is used for the commercial gain of a third party - and where claimants can usually rely on a strong level of legal

\footnotetext{
82 \& 107 US Copyright Act 1977.

83 Döhl (2017), p. 37; European Copyright Society (2017): Opinion on Reference to CJEU in Case C-476/17, Hutter v. Pelham, https://europeancopyrightsociety.org/portfolio/opinion-on-reference-to-cjeuin-casec-476-17-hutter-v-pelham.

84 Personality rights are protected under Art. 23 of the German Artistic Copyright Act (image rights) and Art. 823(1) of the German Civil Code (protection of the general personality right under the tort clause).
} 
protection allowing them to object to commercially motivated uses, such as for advertising purposes - the system remains open so as to integrate freedom of speech concerns, for example where the objectionable advertisement contains political or social comment. ${ }^{85}$

The comparison with general personality rights also highlights that where (as in the Pelham case) a commercial impact is virtually non-existent, the assessment shifts to an open standard so as to reduce complexity via a binary and dialectic evaluation; the conventional categorisation found in copyright law, that is, the axiomatic distinction between the notions of work and exceptions, then becomes irrelevant. The focus thus shifts towards a much more precise and detailed assessment of interests, and these interests are understood as being on a par and of equal weight. Therefore, the distinction between permissible uses that fall within a written exception and de minimis uses that do not is rendered obsolete. In the case of music sampling, the use of freedom of art as a point of departure thereby circumvents the categorical hierarchy that the given architecture of copyright proscribes and thus avoids a "box-ticking" exercise without predetermining the outcome.

Much as in the case of parodies or pastiches of literary works, the openness of the argumentative structure permits numerous criteria to be developed incrementally. In Pelham, for example, the principal motivation of the claimants was very probably not to profit from the sample but to object to a use on the basis of the perceived violation of artistic integrity, and a claim based upon such notion of artistic integrity would immediately have removed the case from scrutiny under EU law. ${ }^{86}$ Thus, what the claimants effectively pursued was an objection to a use in a genre the claimants did not approve, and the central proposition here is whether they could, on balance, rely on a negative freedom of art claim as a specific, and, as far as can be discerned, rather novel concretisation of their collective general personality right - a right to object on the basis of maintaining the sonic integrity and the character of the sounds as being unique and, historically, revolutionary: the Pelham dispute, in reality, displays a collision between two claims to freedom of art.

These deliberations promote a clearer perspective. The approach taken by the Federal Constitutional Court is closer to an understanding of copyright law as an open system where "fairness", much as in the historical perception of the US fairuse clause, ${ }^{87}$ represents the basic norm. It highlights that constitutional obligations to protect user participation rights do not hinge upon an anachronistic and formalistic dichotomy between "work" and "copy". How these interests are realised under an open assessment standard, ${ }^{88}$ and whether or not statutory copyright provides usable mechanisms (such as a new de minimis rule category, free use as under the former Art. 24 of the German Authors' Rights Act, or by way of applying Art. 13 EU Charter directly) is largely irrelevant. In contrast, the Court of

\footnotetext{
85 BGH (2007) GRUR 139 - Lafontaine.

86 See also Opinion AG Szpunar, Case 476/17 - Pelham GmbH and Others v. Ralf Hütter and Florian Schneider-Esleben, ECLI:EU:C:2018:1002, para. 87.

87 Patry (2015), pp. 85, 91.

${ }^{88}$ For a full discussion on the application of the fair-use clause see Rinkerman (2014).
} 
Justice predominantly has to rely on the structure of secondary law, which is, overall, based on opaque notions of property, a dedicated hierarchy between "subject matter" and exception, and an undisclosed and problematic nexus between a high level of protection and market integration aims.

The Court of Justice, in contrast, precludes any meaningful development of its own "open" jurisprudence with regard to de minimis use copyright: to recap, the Court has clearly asserted that copyright must be balanced against third party rights in applying the EU Charter, in addition to creating a novel status of written exceptions as (subjective) rights of users. ${ }^{89}$ Thereby, written exceptions are approximated to a fair-use standard. Here, the dichotomy between work and copy is relinquished. Yet, even despite the breadth of the Deckmyn decision, national courts may, following Art. 5 InfoSoc Directive, constrain the right to parody or pastiche further, for example, by applying the three-step test under Art. 5(5) InfoSoc Directive. $^{90}$

Conversely, the Federal Constitutional Court ensures that formalistic thinking, deeply embedded in the architecture of copyright, ${ }^{91}$ is incapacitated. There is, consequentially, no predefined hierarchy in the treatment of creativity as a societal objective, and no underlying sense of parasitism where two creative efforts must be balanced. Transformative or referential uses of copyright works are no longer subject to a perception of cultural inferiority that must generally be considered as parasitic and, therefore, as exceptions in that word's literal meaning. The Federal Constitutional Court averts such understanding of copyright law and establishes and reconstrues the respective rights; both the copyright work and its referential recreation are treated as equal forms of communication, rather than as property.

\subsection{Interim Conclusion: Different Copyright Architectures and the Closed-List Principle}

In sum, the Federal Constitutional Court is much closer to an understanding of fairness as a central tenet, considering that the Court did not place much emphasis on how copyright could resolve such conflicts, and it was probably irrelevant that copyright law had no statutory mechanism to deal with freedom of art but the illfitting free-use clause. The important conclusion is, arguably: the state is obliged to protect creativity through freedom of art and communication guarantees irrespective of any perceived normative hierarchy as may be perceived from lower ranking law such as copyright, and that includes secondary EU copyright law. The Federal Constitutional Court has - way above and beyond the issues concerning sampling re-established the public interest as being on a par with any commercial or ideational interest. That insight necessitates a clear analysis of the function of each right and interest so as to provide persuasive justifications from a constitutional point of view. The Federal Constitutional Court does not accept the notion of an

\footnotetext{
${ }^{89}$ Case C-469/17, Funke Medien NRW GmbH v. Bundesrepublik Deutschland, ECLI:EU:C:2019:623; Case C-516/17, Spiegel Online GmbH v. Volker Beck, ECLI:EU:C:2019:625.

90 Jütte (2019), p. 52.

91 See Elkin-Koren (2017), pp. 132, 156 et seq.
} 
axiomatically proscribed dichotomy between work and copy, and between right and exception. Instead, copyright protection is perceived as an adaptable and open system. The approach deconstrues the entire architecture underpinning the InfoSoc Directive and DSMD. In essence, the Federal Constitutional Court has hit the weakest spot in EU copyright law: that the closed-list approach in itself is unconstitutional because it impedes a meaningful and rational evolution of the law, and that economic objectives necessarily are obsolete in the balancing exercise. ${ }^{92}$

In contrast, the Court of Justice retains the conventional approach. Exceptions are treated as limited immunities to a predominant rule that assumes protectability and thereby assigns property, a conclusion realised via the right of reproduction as a fully harmonised concept of EU law. This reinforces the misconceived work/copy and property/exception dichotomies and, more importantly, renders fundamental rights a function of anachronistic integration aims via policy objectives derived from secondary law. The approach taken by the Court of Justice is misguided in other respects as well: the impact on market integration aims is, if anything, minimal. The Court of Justice has, probably most importantly, missed the opportunity to clarify the relationship between secondary law and EU Charter rights. With regard to the predictable constitutional challenges, that insistence on the limits imposed by an enumeration of permitted uses shifts the focus away from central fairness and proportionality considerations and reinforces an understanding of a general precedence of and preference for exploiter rights as property rights under, potentially, Art. 17(2) of the EU Charter, in contrast to the Court's own line of reasoning. ${ }^{93}$ The key to that reasoning can be found in previous jurisprudence: fundamental rights are subject to the conditions set by the framework of the EU legal order. ${ }^{94}$

\section{A Strained Relationship: The Constitutionality of Art. 17 DSMD}

The divergent approaches in Pelham will have direct consequences on how the new regime under Art. 17 DSMD will be assessed in terms of constitutional law. For the Federal Constitutional Court, the decisive question will be the openness of the system to accommodate proportionality as a fundamental prerequisite for the law to react to changes in communicative-sensitive spheres, and the constitutional test will predominantly focus on the rights of authors and users. Typical dogmatic categorisations - such as whether copyright law may recognise a de minimis

\footnotetext{
92 See also German Federal Constitutional Court (2008) GRUR 999, 1000 - Printers and Plotters.

93 Which allows the conclusion that Art. 17(2) EU Charter must be construed in the broader framework of primary law; see Case C-70/10, Scarlet Extended NV v. Belgische Verenigung van Auteurs, Componisten en Uitgevers CVBA (SABAM), para. 43, ECLI:EU:C:2011:771; Case C-314/12, UPC Telekabel Wien GmbH v. Constantin Film Verleih GmbH and Wega Filmproduktionsgesellschaft mbH, ECLI:EU:C:2014:192..

94 Opinion of the Court (Full Court) of 18 December 2014, Case Opinion 2/13 - Accession of the European Union to the European Convention for the Protection of Human Rights and Fundamental Freedoms - Compatibility of the draft agreement with the EU and FEU Treaties, ECLI:EU:C:2014:2454
} 
exception, or whether fundamental rights can be applied as external defences - are irrelevant.

\subsection{Article 17 DSMD and the German Federal Constitutional Court: A Prediction}

The approach adopted by the Federal Constitutional Court in Pelham creates numerous strands for a more inclusive recognition of fundamental rights. Without expressly saying so, many of the considerations that can logically follow from the decision were reflected in the first German draft on implementing Art. 17 DSMD. In Pelham, the "practical concordance" test relegates the rights of both exploiters (property) and platforms (freedom to conduct a business) to their proper location within the matrix, which is precisely what the first draft proposal in Germany would have achieved. Both rights can then be perceived as functional in the sense that both actors are to be considered as agents and intermediaries. ${ }^{95}$ Platforms can rely upon the clause on freedom to conduct a business not only because, in general, excessive filtering obligations can become burdensome, but also because such obligations reduce the incentive to invest and innovate at the expense of freedom of communication and ultimately to the detriment of users and authors. ${ }^{96}$ De minimis uses can be integrated into a balancing test because they have no commercial impact, and reliance on freedom of art can be extended to more general freedom of communication concerns. Therefore, the focus in the constitutional analysis with regard to Art. 17 DSMD would primarily, and correctly, lie on the collisions between author and user interests. At this stage, access by and large becomes a necessary precondition for maintaining creative freedom: the first German proposal and its prevalent assurance of collective licensing solutions, coupled with new sources of income to remunerate authors, including for de minimis uses, would have achieved that equilibrium. The draft proposal evidences that the "medium of money" is a workable instrument not only so as to avoid mass filtering as such, but also as the only legislative mechanism that is commensurate with constitutional standards as the least intrusive solution. The political outcome in Germany, which was very much a consequence of exploiters finding fault with the allegedly "excessive" de minimis exception and its alleged incompatibility with secondary law, is a direct consequence of the Pelham decision as predicated on the market prerogative to protect any licensing opportunity.

Further, the Federal Constitutional Court implicitly demands that, because proprietary and technological copyright protection impedes communication, ${ }^{97}$ courts must demonstrate an awareness that the constitutional implications have been recognised. As mentioned, this is not a matter of finding the right mechanism in copyright statutes or doctrine, but a matter of open standards that guide the judge, methodically, towards intricate questions concerning the function of subjective

\footnotetext{
95 Luhmann (2015) [originally published in 1970], pp. 360, 367

96 For a comprehensive discussion see Wu (2018) passim.

97 See Teubner (2004), pp. 3, 5.
} 
rights and their respective weight. ${ }^{98}$ The Court, in essence, posits that the resolution of conflicting interests must be made exclusively within the legal system, and it is that assertion that would immediately disqualify any solution based on technological control as unconstitutional and disproportionate, because only the system of fundamental rights itself can allocate rights and apportion the relevant weight to each interest.

The Federal Constitutional Court thus categorically refuses to accept EU law where communicative freedoms are subjected and subordinated to mechanisms, such as the closed-list principle under Art. 5 InfoSoc Directive, that predominantly serve harmonisation aims, and would arguably also reject any reliance upon a high level of protection for the benefit of exploiter rights, especially so where legal reasoning is removed and replaced with technological control. Technological decision-making directly collides with the need for a continued openness of the legal system because it impedes the adaptability of the legal systems and the need to adjust any legal rule that protects information to changing social and technological realities. Artificial intelligence may, with much trepidation, sometime in the future, be able to detect certain permissible uses, ${ }^{99}$ but computer code cannot mirror constitutional dynamics. If the elasticity of the legal system is eradicated through technological control, and if the right to one's free development of personality is so significantly impeded through surveillance as to produce widespread deterrence, the violation of constitutional guarantees is obvious.

\subsection{Conditions for Participation: Self-Determination and Surveillance}

At this juncture, the nexus between self-determination, free development of one's personality and communicative freedom in the context of platform liability becomes obvious. As mentioned, users may well, even where the uploaded content is permissible and has been flagged as such, be dragged into disputes with right holders, and thus be subjected indirectly to surveillance measures and threats to privacy. Right holders will (and do) pursue aggressive policies targeting each and any use, ${ }^{100}$ and platforms may enjoin them so as to avoid liability. All this is not new - right holders have, of course, strategically targeted users ever since the advent of the internet so as to achieve a maximum discouraging effect. ${ }^{101}$ Even so, the dissuading consequence of Art. 17 DSMD is to reduce what is available on platforms irrespective of whether the content in question constitutes a straightforward copy, whether the use may be covered under an exception, or whether no copyright infringement has occurred at all. If access to platforms as culturally valuable communicative fora is socially desirable, participation must be guaranteed

\footnotetext{
98 See, on the function of rights, Luhmann (2015), pp. 360, 367. Luhmann insightfully demonstrates that rights relating to property, at a highly abstract level, are malleable in giving the lawmaker extensive choices. Thus, the equilibrium to be struck, for example between landlord and tenant with regard to the rights to terminate a lease, has little to do with constitutionally informed balancing or indeed justice as such, but can be fully justified based on legislative objectives of (housing) market regulation.

99 See Burk (2019), pp. 283, 289 et seq.

100 See Rinkerman (2014).

101 Yu (2015), pp. 455, 459; Penney (2019).
} 
and deterrence prevented, and such objective necessitates a certain degree of accepting copyright infringement. The liberty to use small parts, accordingly, is an imperative precondition for participation. It is directly linked to creativity, as the Federal Constitutional Court has shown, but is also linked to more extensive freedom of communication concerns - for example, in the context of educational videos, for which Art. 17(7) DSMD makes no provision at all. Without such freedom, the very initial condition for participation is eradicated as threats of infringement remove confidence and motivation.

Thus, the assertions of the Federal Constitutional Court as regards freedom of art can be stretched to broader freedom of communication rights, ultimately inferred from the right to self-development of one's personality. This conclusion is unavoidable, and obviously counter arguments based on commercial licensability are untenable. The (subjective) rights of users must therefore be exercisable without imposing a psychological barrier, and these corollaries can readily be inferred from the Pelham decision itself. In conclusion, the potential to deter not only creativity but also possibly any motivation to participate on platforms would, following the fundamental assertion made by the Federal Constitutional Court in its groundbreaking "Population Census" decision, ${ }^{102}$ be sufficient to disqualify Art. 17 DSMD: a system that is designed to shatter the confidence of users by exposing them to threats of damages and litigation has exactly the effect that the Court has denounced as incompatible with the right to development of one's personality. Again, the first German draft sought to avoid exactly that situation in allowing "technically verifiable" de minimis uses. The Pelham decision, in this regard, is a first instalment - an exercise that sets, albeit subtly, the scene for constitutional complaints that will challenge Art. 17 DSMD.

\section{The Court of Justice, Copyright and the Primacy of the EU Legal Order}

The tendency in the Court of Justice's ruling in Pelham to maintain judicial control very arguably leads to an entirely different approach when the constitutionality of Art. 17 DSMD is challenged. It is certainly unfortunate that the Court of Justice did not see itself in a position to "elevate" the general permissibility of referential or transformative uses to the status of fundamental rights, as it very arguably did, as discussed, in the case of parody. The effect is a direct collision course. The Court of Justice appears willing to sacrifice elementary conditions for future evolution and malleability of the EU copyright system, and the principal motivation for maintaining the "closed-list" principle as regards exceptions and limitations, and the need for its uniform application, obviously stem from a continuous orientation towards the aim of an "ever closer union", as the most fundamental objective transgressing EU law-making and its orientation towards market integration. ${ }^{103}$ It thereby established a collision clause as a strict demarcation line between national

\footnotetext{
${ }^{102}$ German Federal Constitutional Court 1 BvR 209/83, BVerfGE 65, 1, 43; see Hornung and Schnabel (2009), p. 84.

103 Art. 1(2) TEU.
} 
constitutional law and secondary law, and effectively disallows arguments for a continued constitutional pluralism. Thus, under secondary law, proportionality may be dispensed with unless proscribed through specific permitted purposes. Both the InfoSoc Directive and DSMD contain a plethora of references from which a fundamental principle of a high level of protection can be extrapolated. This "high level" can easily integrate technological enforcement prerogatives. The closed-list principle, under that reading, can be understood in a broader sense: accordingly, the closed list not only serves harmonisation purposes, but is also in line with the apparent purpose of the high-level tenet, which is to create and improve market integration through strong control rights protected as fundamental freedoms under primary law. ${ }^{104}$

\subsection{Market Integration and Platform Liability}

That line of reasoning results in two possible conclusions. As regards the relevance of freedom of art and communication, the fundamental rights factor can easily be subject to predominant (digital) market integration aims and thus permit exploiters to rely on protection under primary EU fundamental freedom laws as regards the freedom of services in particular. At this juncture, complex and critical questions as regards the relationship between fundamental freedoms and the rights under the EU Charter emerge, which raise questions as to how conflicts between these two bodies of primary law are resolved as a matter of normative hierarchies in EU law in general. The debate surrounding this conflict within the EU legal order cannot be presented here comprehensively, ${ }^{105}$ and it suffices to state that many commentators have identified a certain debatable tendency in the jurisprudence of the Court of Justice, that is, an inclination to over-emphasise fundamental freedoms, economic principles and the integrity of the EU legal order. As a consequence, the status of fundamental rights is subject to a balancing test under which fundamental rights become an undesirable obstacle to market integration aims. ${ }^{106}$ The second conclusion automatically follows: if exploiters can rely on fundamental freedoms, the property clause in Art. 17(2) of the EU Charter sets the primary point of departure for the constitutional assessment. Article 17(2) of the EU Charter does not give absolute protection whatsoever, ${ }^{107}$ but, necessarily, the weight assigned to exploiter rights is abstractedly greater where Art. 17(2) of the EU Charter is pitted primarily or only against the right of platforms under Art. 16 of the EU Charter precisely the approach the Court of Justice has so far adopted. ${ }^{108}$

\footnotetext{
104 Conversely, private defendants in copyright disputes cannot invoke the fundamental freedom to provide services or the rules on competition law so as to surpass secondary copyright rules, see Case C-403/08, Football Association Premier League Ltd and Others v. QC Leisure and Others and C-429/08 Karen Murphy v. Media Protection Services Ltd, ECLI:EU:C:2011:631.

105 See comprehensively de Vries (2013), p. 169.

106 See further Itzcovich (2012), p. 358.

107 Case C-70/10, Scarlet Extended NV v. Belgische Verenigung van Auteurs, Componisten en Uitgevers CVBA (SABAM), ECLI:EU:C:2011:771, para. 32.

108 Ibid., para. 46.
} 
Consequently, the latitude in the assessment is considerably narrowed, and the decisive considerations then concern predominantly the degree to which the imposition of filtering and/or monitoring obligations is overly burdensome.To be fair, the Court of Justice referred to user rights, including freedom of expression ${ }^{109}$ and privacy, ${ }^{110}$ but these considerations were not decisive, and the relevance of these rights remains open. ${ }^{111}$ Users still have (subjective) rights under written exceptions, but freedom of communication cannot be invoked by internet users beyond the closed list. ${ }^{112}$ Article 17 DSMD will, of course, render obsolete many of the arguments that platforms have successfully raised in the past, both as regards freedom to conduct a business and the safe harbour provision. Now, the "best effort" condition under Art. 17 DSMD leads to tacit collusion between exploiters and platforms, as is intended. ${ }^{113}$ In sum, the new obligations almost coerce the Court of Justice to accept the detrimental effects that proactive filtering will have on freedom of art and communication - as tolerable collateral damage with minor implications in light of the objective of a high level of protection, and that conclusion follows precisely from the stance the Court adopted in Pelham.

\subsection{Cooperation or Conflict? Article 17 DSMD and Two Constitutional Cultures}

The collisions that have emerged following Pelham thus exceed copyright law issues by far. The lack of acceptance of a slightly more liberal approach by the Court of Justice now means that the closed-list principle is cemented, a position that will make it extremely difficult for the Court of Justice to reintegrate concerns over freedom of art and speech when deciding on the constitutionality of Art. 17 DSMD, notwithstanding the plethora of arguments that can be raised in favour of strong exploiter rights. The stance adopted by the Federal Constitutional Court in Pelham, in view of a potential constitutional challenge against the new German Copyright Service Providers Act under national law, is diametrically opposed to EU legal order arguments: the rights to be balanced are those of authors and users, with a strong emphasis on (1) freedom of art and communication, (2) the dangers of technical surveillance, and (3) more general constitutional observations with regard to the interface between technological enforcement and the dangers that a "code as code" solution brings about for the capacity of the legal system - as a system of communication - to develop. Consequently, the rights of exploiters and platforms must be considered as subservient to those of users and authors.

In conclusion, the point of departure as adopted by the Federal Constitutional Court will, if generalised, cause radical regime collisions between national constitutional law and the EU legal order. It is to be expected that the Court will not accept a situation where freedom of art and communication is stifled, and

\footnotetext{
109 Art. 11 of the EU Charter.

110 Art. 8 of the EU Charter.

111 See critically Mylly (2014), pp. 103, 115.

112 See Fischer-Lescano (2014), p. 965 (discussing the complexities associated with constitutionalising "user rights" as reflections of claims to freedom in relation to internet governance).

113 Recital 62 DSMD.
} 
especially not where complex decisions affecting freedom of speech are executed in the context of private dispute resolution mechanisms by platform employees whose decision-making tendency principally depends on their employers' strategy to avoid liability. ${ }^{114}$ The Court will also not consent to any solution that subordinates an understanding of fundamental rights in accordance with national constitutional law to an impervious preference for primary EU law and market integration aims or, for that matter, an obscure preference for "property" protection designed to reallocate unjustified enrichments under a simplistic policy to bridge a value gap - especially not given that freedom of communication has always been considered the central fixation point in the "objective order of values" under domestic constitutional law. ${ }^{115}$

\subsection{Constitutional Pluralism, Strategic Decision Making and Copyright Policy: A New Collision Course}

The Pelham controversy thus impressively demonstrates the potential for a sweeping conflict not only between the Federal Constitutional Court and the Court of Justice, but between divergent constitutional orders. The very same collision reemerges now in the context of Art. 17 DSMD. And - way above and beyond that issue - the potentially divergent approaches to questions of constitutionality in copyright can have far-reaching consequences of an unprecedented magnitude for the entire system of secondary copyright law and its capability to co-exist with national constitutional principles: ultimately, the opposing views expressed display predominantly strategic decision-making - to secure as much competence as possible. A bifurcated approach would follow.

It is of note that the Federal Constitutional Court's Pelham decision at no point discusses Art. 5 InfoSoc Directive as such. Presumably, this is no coincidence. Ignoring any obligation to follow EU law allowed that Court to clarify the intersection between copyright law and constitutional law, also with a view to Charter rights. The Court sent a clear signal to the Court of Justice that secondary law and uniformity of interpretation have little impact on domestic guarantees and the continued applicability of proportionality principles. It is maybe also not a coincidence that the Pelham decision came shortly before the Federal Constitutional Court adopted a new approach that noticeably seeks afresh to rebalance the relationship between national constitutional guarantees and the principle of the primacy of the EU legal order, a stance that has always been rejected by the Court of Justice, which demands absolute primacy of EU law. ${ }^{116}$ One may speculate that the confrontational course the Federal Constitutional Court adopted is a deliberate move to regain control precisely over the new liability concept under Art. 17 DSMD, all

\footnotetext{
114 See, with regard to the constitutional impermissibility of subsequent ex post dispute resolution mechanisms, AG Saugmandsgaard Øe, Case C-401/19, Republic of Poland v. European Parliament and Council of the European Union, ECLI:EU:C:2021:613, paras. 180 et seq.

115 BVerfGE 7, 198 - Lüth.

116 Since Case C-6/64, Costa v. E.N.E.L. [1964] ECR I 1251, 1269. See Ludwigs and Sikora (2016), p. 121 .
} 
the more so since the mutually exclusive views exhibited by the two courts respectively will make cooperative dialogue ${ }^{117}$ almost impossible.

Indeed, the confrontations in Pelham are not singular occurrences in the relationship between the two courts. The Federal Constitutional Court now adopts a highly critical view on the supremacy of the EU legal order, and has changed its jurisprudence on the relationship between national constitutional law and EU law drastically. In recent decisions, unrelated to copyright law, the Court fervently reclaimed competence over the interpretation of fundamental rights, including the rights under the Charter, ${ }^{118}$ thus asserting that the Federal Constitutional Court would no longer be content with mere control of identity between domestic and EU fundamental rights, ${ }^{119}$ to be interpreted in detail by the Court of Justice.

Moreover, the Court affirmed a shift from its previous accommodating approval of the primacy of the EU legal order ${ }^{120}$ as regards, specifically, the status of proportionality: the Federal Constitutional Court now blatantly refuses to follow the Court of Justice ${ }^{121}$ where it considers its decisions ultra vires. ${ }^{122}$ This is the case where the EU, in the opinion of the Federal Constitutional Court, does not satisfactorily explicate if and how proportionality deliberations have been undertaken - for example, where the considerations of the Court of Justice appear unintelligible or arbitrary, or where, more importantly, proportionality assertions based on fundamental rights are absent. ${ }^{123}$ It is especially deficient, according to the Federal Constitutional Court, for the Court of Justice or other organs of the EU to merely conduct an assessment relating to the reasonability of EU measures. ${ }^{124}$

Academic commentary (unrelated to copyright law) had already identified the cause for that development as, precisely, the recurrent propensity in EU legislation and the related jurisprudence of the Court of Justice to prioritise integration aims over fundamental rights, ${ }^{125}$ often coupled with a shrewd tendency to increasingly secure competences through extending the realms of autonomous interpretation, which triggered the Federal Constitutional Court to retort. ${ }^{126}$ Unsurprisingly, the emphasis the Court of Justice places upon market integration objectives and uniform

\footnotetext{
117 Cf. generally Tridimas (2015), p. 403.

118 German Federal Constitutional Court (2020) Neue Juristische Wochenschrift (NJW) 1647 - Right to be Forgotten I. The German Federal Constitutional Court here refers to its Pelham decision (BVerfGE 142, 313, 345). The German Federal Constitutional Court asserts that European, international and other supranational catalogues of fundamental and human rights can serve as inspiration for domestic interpretation, but that there is no principle that the Court is bound to adopt an interpretation of open constitutional norms that deviates from international or European decision-making instances.

119 BVerfGE 126, 286 - Honeywell.

120 BVerfGE 126, 286, 294 - Honeywell.

121 Case C-493/17, Proceedings brought by Heinrich Weiss and Others, ECLI ECLI:EU:C:2018:1000.

122 German Federal Constitutional Court (2020) Neue Juristische Wochenschrift (NJW) 1647. See further Grimm (2020), p. 944 = https://doi.org/10.1017/glj.2020.55; Nettesheim (2020), p. 1631.

123 Nagy (2020), pp. 838, 842 et seq. $=$ https://doi.org/10.1017/glj.2020.44.

124 German Federal Constitutional Court (2020) Neue Juristische Wochenschrift (NJW) 1647, para. 53 Right to be Forgotten I.

125 Conway (2012), passim; Conway (2010), p. 966.

126 Grimm (2020), pp. 944, 947 = https://doi.org/10.1017/glj.2020.55.
} 
interpretation $^{127}$ results in a decision-making programme in which fundamental rights can easily become submerged and subject to higher ranking economic policy objectives. ${ }^{128}$ The Federal Constitutional Court implicitly exposed the "closed-list" principle as the fundamental flaw in secondary copyright law. The Court identified the "closed-list" argument as devoid of substance, its function limited to that of a convenient collision clause for the Court of Justice to exercise control over any constellation concerning the potential impact of fundamental rights upon secondary law principles. ${ }^{129}$ The Court will have been fully aware when considering the Pelham case that its own approach is not compliant with Art. 5 InfoSoc Directive, and that the German Federal Supreme Court would feel obliged to present the case to the Court of Justice for a preliminary ruling. The Pelham case, with its innumerable intricacies, provided a most suitable opportunity for the Federal Constitutional Court to, almost perfidiously, provoke a decision of the Court of Justice that would, expressly, exclude fundamental guarantees from the canon of EU copyright law. The Court of Justice thus could only react through adopting its peculiar "perceptibility" solution: any direct answer to the question of how freedom of art relates to copyright would have necessitated some statement on competences, the degree of harmonisation and, most worryingly from the perspective of uniform interpretation, the relationship between national constitutional law and the rights under the Charter ${ }^{130}$ - deliberations at a level of inquiry at which the conventional apodictic assertions of autonomous interpretation and references to full harmonisation would no longer have credibly worked.

Now, the Federal Constitutional Court can regain control, and can do so by referring to both domestic constitutional rights as well as the rights under the Charter. It may lead back to the previous licensing solution as the least intrusive means as a focal point. The Court of Justice will have to accept such reestablishment of constitutional plurality. In turn, and to regain competence over copyright, the Court of Justice is forced to emphasise fundamental rights and proportionality, and thus to bring the jurisprudence of the Court in Justice in line with domestic perceptions on fundamental rights guarantees. In the event that the Court of Justice finds that Art. 17 DSMD is compliant with fundamental rights, the Federal Constitutional Court may still declare such decision as non-binding. The probable effect of such essentially confrontational dialogue may well be an incremental realignment away from economic considerations. For the Court of Justice, the challenge brought by Poland can thus be considered an opportunity, far above and beyond copyright law. The major constitutional objections - the need to

\footnotetext{
127 On the relationship between the collision clauses in Arts. 51-53 of the EU Charter and fundamental freedoms see Case C-399/11, Stefano Melloni v. Ministerio Fiscal, ECLI:EU:C:2013:107, paras. 55 et seq.; Case C-617/10, Åklagaren v. Hans Åkerberg Fransson. ECLI:EU:C:2013:105, paras. 45 et seq.

128 Evident in the approach taken in: Opinion of the Court (Full Court) of 18 December 2014, Case Opinion 2/13 - Accession of the European Union to the European Convention for the Protection of Human Rights and Fundamental Freedoms - Compatibility of the draft agreement with the EU and FEU Treaties, ECLI:EU:C:2014:2454; see critically Nettesheim (2016), p. 424.

129 Which may then easily extend to non-harmonised areas such as authors' personality or moral rights, as the Deckmyn decision amply demonstrates. See Rosati (2015), p. 511.

130 See Kingreen (2018), para. 4.
} 
avoid preventive filtering and the associated perils of privatised dispute resolution mechanisms - may well result in annulling Art. 17 DSMD; after all, if these elements are removed from the general concept not much will be left but a return to existing and standard notice and takedown practices.

\section{Conclusion}

The new liability regime establishes a system of enforcement generating an overabundance of constitutional challenges. Its major flaw lies in misconceiving the intersection between technological enforcement and resultant surveillance by way of automated decision making on the one hand and its impact on socially and culturally desirable user behaviour coupled with an exaggerated bias towards commercial rights and economic integration aims. Technological solutions contravene fundamental principles of copyright law as a body of rules that predominantly aims to foster creativity.

The two opposing decisions in Pelham signal a disturbing inclination for EU copyright law in general. It is rather obvious that Art. 17 DSMD will not pass constitutional scrutiny before the German Federal Constitutional Court, and, if the provision is challenged before that Court, it can be expected that freedom of art and communication, and proportionality requirements more generally, will provide the focus of the constitutional assessment as regards producer rights and their function in particular. That analysis would unveil severe weaknesses in the customary reliance on property arguments, and the pyramidical architecture of secondary copyright that places commercial privileges and technological control on top. If the Federal Constitutional Court, in keeping with its current approach to increase the density of control over fundamental rights and the proper execution of proportionality standards, concludes in favour of communicative freedoms, the effects will inevitably transgress Art. 17 DSMD. It could cause the entire architecture of secondary copyright law to collapse.

Open Access This article is licensed under a Creative Commons Attribution 4.0 International License, which permits use, sharing, adaptation, distribution and reproduction in any medium or format, as long as you give appropriate credit to the original author(s) and the source, provide a link to the Creative Commons licence, and indicate if changes were made. The images or other third party material in this article are included in the article's Creative Commons licence, unless indicated otherwise in a credit line to the material. If material is not included in the article's Creative Commons licence and your intended use is not permitted by statutory regulation or exceeds the permitted use, you will need to obtain permission directly from the copyright holder. To view a copy of this licence, visit http:// creativecommons.org/licenses/by/4.0/.

\section{References}

Akester P (2009) Technological accommodation of conflicts between freedom of expression and DRM: the first empirical assessment. SSRN J. https://ssrn.com/abstract=1469412

Burk D (2019) Algorithmic fair use. Univ Chicago L. Rev 86(2019):283-307 
Cahir J (2007) The structure of control - communication systems and copyright law. In: Westkamp G (ed) Emerging issues in modern intellectual property: trade, technology, market freedom, essays in memory of Herchel Smith. Edward Elgar, Cheltenham, pp 73-87

Christoffersen J (2017) The principle of proportionality: human rights and balancing. In: Geiger C (ed) Research handbook on human rights and intellectual property (Cheltenham 2017), pp 19-37

Conway J (2010) Conflicts of competence norms in EU law and the legal reasoning of the ECJ. German Law J 11:966-1005

Conway J (2012) The limits of legal reasoning and the European Court of Justice. Cambridge University Press, Cambridge

de Beer JF (2005) Constitutional jurisdiction over paracopyright laws. In: Geist M (ed) In the public interest: the future of copyright law in Canada. Irwine Law, Toronto, pp 89-124

de Vries S (2013) Balancing fundamental rights with economic freedoms according to the European Court of Justice. Utrecht Law Rev 9(1):169-192

Döhl F (2017) The concept of "pastiche" in Directive 2001/29/EC in the light of the German case Metall auf Metall. Media Action Interdiscip J Coop Med 2:37-64

Dusollier S (1999) Electrifying the fence: the legal protection of technological measures for protecting copyright. Eur Intellect Prop Rev (EIPR) 6:285-297

Elkin-Koren N (2017) Copyright in a digital ecosystem. In: Okediji R, Hugenholtz PB (eds) Copyright in an age of limitations and exceptions. Cambridge University Press, Cambridge, pp 132-168

European Commission (2020) Targeted consultation addressed to the participants to the stakeholder dialogue on Article 17 of the Directive on Copyright in the Digital Single Market (27.7.2020) https://ec.europa.eu/digital-single-market/en/stakeholder-dialogue-application-article-17-directivecopyright-digital-single-market

European Copyright Society (2017) Opinion on reference to CJEU in case C-476/17, Hütter v. Pelham https://europeancopyrightsociety.org/portfolio/opinion-on-reference-to-cjeu-in-casec-476-17-hutterv-pelham

Fischer-Lescano A (2014) Der Kampf um die Internetverfassung. Juristenzeitung (JZ), 965-974

Flür W (2017) Kraftwerk: I was a robot. Music Sales Ltd, London

Frosio G (2017) The death of 'no monitoring' obligations: a story of untameable monsters. JIPITEC 8:199-215

Geiger C, Frosio G, Izyumenko T (2019) Intermediary liability and fundamental rights. In: Frosio G (ed) Handbook on online intermediary liability. Oxford University Press, Oxford, pp 138-154

Geiger C, Izyumenko T (2019) Blocking orders - assessing tensions with human rights, intermediary liability and fundamental rights. In: Frosio G (ed) Handbook on online intermediary liability. Oxford University Press, Oxford, pp 566-585

Griffiths J (2017) Fair dealing after Deckmyn - the United Kingdom's defence for caricature, parody \& pastiche. In: Richardson M, Ricketson S (eds) Research handbook on intellectual property in media and entertainment. Edward Elgar, Cheltenham, pp 64-102

Grimm D (2020) A long time coming. German Law Journal 21(5):944. https://doi.org/10.1017/glj.2020. 55

Hoeren T (2000) Sounds von der Datenbank - Zum Schutz des Tonträgerherstellers gegen Sampling. In: Schertz C, Omsels H-J (eds) Festschrift für Paul W. Hertin zum 60. Geburtstag, pp 113-132. Munich

Hoeren T, Yankova L (2012) The liability of internet intermediaries - the German perspective. IIC 11:501-531

Hoffmann D, Klass N (2017) The reference as part of the art form: a turning point in copyright law? Media Action Interdiscip J Coop Med 6:31-36

Hofmann F (2020) Plattformregulierung im Lichte des Unionsrechts. Kommentar zum Diskussionsentwurf des BMJV v. 24.6.2020 zu einem Zweiten Gesetz zur Anpassung des Urheberrechts an die Erfordernisse des digitalen Binnenmarktes. Zeitschrift für Urheber- und Medienrecht (ZUM) $665-670$

Hornung G, Schnabel C (2009) Data protection in Germany I: the Population Census decision and the right to informational self-determination. Comput Law Secur Rev (CLRS) 24(1):84-88

Hufen F (2019) Staatsrecht II: Grundrechte. 8th edn. Verlag CH Beck, Munich

Hugenholtz PB (2013) Is harmonization a good thing? the case of the copyright acquis. In: Pila J, Ohly A (eds) The Europeanization of intellectual property law. OUP, Oxford, pp 57-73

Hugenholtz PB (2019) Neighbouring rights are obsolete. IIC 50:1006-1010 
Husovec M (2019) Remedies first, liability second. Or why we fail to agree on optimal design on intermediary liability. In: Frosio G (ed) The Oxford handbook of online intermediary liability. Oxford University Press, Oxford, pp 92-103

Husovec M (2019) The essence of intellectual property rights under Article 17(2) of the EU Charter. German Law J 20(6):840-863

Itzcovich G (2012) Legal order, legal pluralism, fundamental principles. Europe and its law in three concepts. Eur Law J (ELJ) 18(3):358-384

Jütte B (2019) The limited effects of fundamental rights on copyright exceptions. Medien und Recht International (M\&R Int.) 16(2):52-55

Kingreen T (2018) Artikel 53 EU-Grundrechtecharta. In: Callies C, Ruffert M (eds) EUV/AEUV, Kommentar. Verlag CH Beck, Munich

Ladeur K-H (2016) Kunstfreiheit und geistiges Eigentum. Zur Entscheidung des BVerfG v. 31.5.2016. 1 BvR 1585/13. Zeitschrift für Geistiges Eigentum (ZGE/IPJ) 15:447-461

Leistner M, Metzger A (2017) The EU copyright package: a way out of the dilemma in two stages. IIC 48:381-384

Lucas-Schloetter A (2019) Kreative Referenzkultur und Urheberrecht in Frankreich. Zeitschrift für Medienrecht und Medienwissenschaft (UFITA) 83(1):99-106

Ludwigs M, Sikora P (2016) Der Vorrang des Unionsrechts unter Kontrollvorbehalt des BVerfG. Europäisches Wirtschafts- und Steuerrecht. (EWS) 3:121-131

Luhmann N (1981) Subjektive Rechte: Zum Umbau des Rechtsbewußtseins für die moderne Gesellschaft. In: Luhmann N (ed) Gesellschaftsstruktur und Semantik. Studien zur Wissenssoziologie der modernen Gesellschaft, Vol. 2, 45-104. Suhrkamp, Frankfurt am Main

Luhmann N (2015) Zur Funktion der subjektiven Rechte. In: Luhmann N (ed) Ausdifferenzierung des Rechts - Beiträge zur Rechtssoziologie und Rechtstheorie, 2nd edn. Suhrkamp, Frankfurt am Main, pp 360-373

Mimler M (2017) 'Metall auf Metall' - the German Federal Constitutional Court discusses the permissibility of sampling music tracks. Queen Mary J Intellect Prop 7(1):119-127

Mylly T (2014) The constituionalization of the European legal order: impact of human rights on intellectual property in the EU. In: Geiger C (ed) Research handbook on human rights and intellectual property, pp 103-131. Edwrad Elgar, Cheltenham.

Nagy CI (2020) The diagonality problem of the EU rule of law and human rights: proposal for an incorporation à l'européenne. German Law J 21(5):838-866. https://doi.org/10.1017/glj.2020.44

Nettesheim M (2016) Anmerkung. Juristenzeitung (JZ) 71:424-426

Nettesheim M (2020) Das PSPP-Urteil des BVerfG: ein Angriff auf die EU? Neue Juristische Wochenzeitschrift 73:1631-1634

Ohly A (2014) Urheberrecht in der digitalen Welt - Brauchen wir neue Regelungen zum Urheberrecht und zu dessen Durchsetzung, Gutachten Teil F. In: DJT, 70. Deutscher Juristentag

Patry W (2015) Few observations about the state of copyright law. In: Okediji RL (ed) Copyright law in an age of exceptions and limitations. Cambridge University Press, Cambridge, pp 85-106

Penney J (2019) Privacy and legal automation: the DMCA as a case study. Stanf Technol Law Rev 22(2):412-448

Quintais P, Frosio G, van Gompel S, Hugenholtz PB, Husovec M, Jütte B, Senftleben M (2019) Safeguarding user freedoms in implementing Article 17 of the Copyright in the Digital Single Market Directive: recommendations from European Academics. https://ssrn.com/abstract=3484968

Rinkerman G (2014) Sampling unleashed? migrating visual art fair use principles into the music space. SSRN J. https://ssrn.com/abstract=2540345

Rosati E (2020) The legal nature of Article 17 of the Copyright DSM Directive, the (lack of) freedom of Member States, and why the German implementation proposal is not compatible with EU law. IP Kitten Blogspot < https://ipkitten.blogspot.com/2020/08/the-legal-nature-of-article-17-of.html> (16.12.2020)

Rosati E (2015) Just a laughing matter? Why the decision in Deckmyn is broader than parody. Common Market Law Rev 52(5):511-529

Senftleben M (2019) Bermuda Triangle - licensing, filtering and privileging user-generated content under the new Directive on Copyright in the Digital Single Market. SSRN Electron J. https://doi.org/10. 2139/ssrn.3367219

Sganga C (2019) The fundamental rights saga in EU copyright law: time for the boundary-setting season? Medien und Recht International 56-62 
Stieper M (2020) Das Verhältnis der verpflichtenden Schranken der DSM-RL zu den optionalen Schranken der InfoSoc-RL. GRUR 122(1):1-6

Teubner G (2004) Societal constitutionalism: alternatives to state-cantered constitutional theory? In: Joerges C, Sand I-J, Teubner G (eds) Constitutionalism and transnational governance, pp 3-28. Oxford

Tridimas T (2015) The ECJ and the national courts: dialogue, co-operation, and instability. In: Chalmers D, Arnull A (eds) The Oxford handbook of European Union law. Oxford University Press, Oxford, pp 403-430

van der Sloot B (2015) Welcome to the jungle: the liability of internet intermediaries for privacy violations in Europe. JIPITEC 6(2):211-228

Westkamp G (2009) Code protection, end users and fair use: mutations of the copyright nexus debate. Comput Law Rev Int (CRi) 4:104-109

Westkamp G (2011) Code, copyright, competition: the subversive force of para-copyright and the need for an unfair competition based re-assessment of DRM laws after Infopaq. J Copyright Soc USA 58(2):601-667

Westkamp G (2019) Referenz und Transformation im britischen Copyright Law. Zeitschrift für Medienrecht und Medienwissenschaft (UFITA) 83(1):42-61

Westkamp G (2011) Code, copyright, competition: the subversive force of para-copyright and the need for an unfair competition based re-assessment of DRM laws after Infopaq. J Copyright Society of the USA 58(2):60

Westkamp G (2008) The 'three-step test' and national decision making in Europe: European Copyright law between approximation and national decision making. J Cop Soc USA 56(1):1

Wielsch D (2008) Zugangsregeln: Die Rechtsverfassung der Wissensteilung. Mohr Siebeck, Tübigen

Wielsch D (2016) Kunst ist mehr als nur Investition: zum Sampling-Urteil des BVerfG. VerfBlog. https:// verfassungsblog.de/kunst-ist-mehr-als-nur-investition-zum-sampling-urteil-des-bverfg/, https://doi. org/10.17176/20160601-134453

Wu P (2018) The curse of bigness: antitrust in the new gilded age. Columbia Global Reports, New York

Yu P (2015) Digital copyright enforcement measures and their human rights threats. In: Geiger C (ed) Research handbook on human rights and intellectual property. Edward Elgar, Cheltenham, pp 455-478

Publisher's Note Springer Nature remains neutral with regard to jurisdictional claims in published maps and institutional affiliations. 